Primljen / Received: 22.10.2013. Ispravljen / Corrected: 26.12.2013.

Prihvaćen / Accepted: 10.1.2014.

Dostupno online / Available online: 10.2.2014.

\section{Adjustment of small-span masonry arch bridges to present-day demands}

Authors:

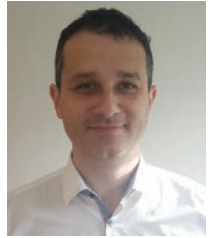

Alex Kindij, PhD. CE PB Palmotićeva 45 alex.kindij@p45.hr

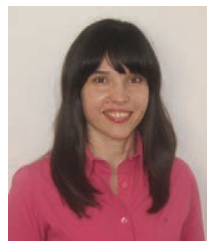

Assist.Prof. Ana Mandić Ivanković, PhD. CE University of Zagreb

Faculty of Civil Engineering

Zavod za konstrukcije

mandicka@grad.hr

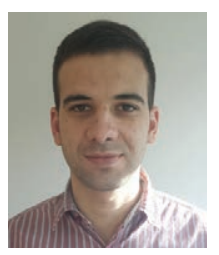

Marin Vasilj, BSc. CE

PB Palmotićeva 45

marin.vasilj@p45.hr
Alex Kindij, Ana Mandić Ivanković, Marin Vasilj

Professional paper

\section{Adjustment of small-span masonry arch bridges to present-day demands}

An overview of deterioration mechanisms and damage to masonry arch bridges, methods for inspection of existing structures, and conservative and sophisticated assessment methods, is presented in this paper. An original preliminary assessment procedure is developed based on the analysis of small-span masonry arch bridges using three conservative assessment methods, and an additional analysis of strengthening and adjustment of these bridges during their service life to modern traffic demands. The procedure contains three basic steps: data collection, arch assessment, and deck slab assessment.

Key words:
assessment, masonry arch bridge, small spans, concrete deck slab, real traffic load

Stručni rad

Alex Kindij, Ana Mandić Ivanković, Marin Vasilj

\section{Zidani svodeni mostovi malih raspona prilagodeni suvremenim zahtjevima}

U radu je dan pregled mehanizama razaranja i oštećenja zidanih svodenih mostova, metoda ispitivanja za utvrđivanje svojstava postojećih konstrukcija te konzervativnih i sofisticiranih metoda ocjenjivanja. Na temelju analiza svođenih mostova malih raspona provedenih trima konzervativnim metodama ocjenjivanja i dodatnih razmatranja učinaka pojačavanja i prilagodbe ovih mostova u njihovom vijeku trajanja suvremenim prometnim zahtjevima, razvijena je izvorna procedura preliminarnog ocjenjivanja koja sadržava tri osnovna koraka: prikupljanje podataka, ocjenjivanje svoda i ocjenjivanje kolničke ploče.

Ključne riječi:

ocjenjivanje, zidani svodeni most, mali rasponi, betonska kolnička ploča, stvarno prometno opterećenje

Fachbericht

Alex Kindij, Ana Mandić Ivanković, Marin Vasilj

\section{Anpassung von Bogenbrücken aus Mauerwerk kleiner Spannweiten an heutige Anforderungen}

In der vorliegenden Arbeit ist für Bogenbrücken aus Mauerwerk ein Überblick der Beschädigungsmechanismen und möglichen Schäden, der entsprechenden Methoden für die Inspektion bestehender Konstruktionen, sowie der konservativen und sophistischen Bewertungsmethoden gegeben. Auf der Analyse von Bogenbrücken aus Mauerwerk kleiner Spannweiten beruhend, durch die Anwendung drei konservativer Bewertungsmethoden und zusätzlicher Analysen möglicher Verstärkungen und Anpassungen an moderne Verkehrsanforderungen im Laufe der Lebensdauer, ist ein originales Verfahren für vorläufige Begutachtungen entwickelt worden. Der Vorgang besteht aus drei Schritten: Datensammlung, Beurteilung des Bogens und Beurteilung der Fahrbahnplatte. 


\section{Introduction}

The existing masonry arch bridges were created in different periods, in different historical situations, and under different environmental circumstances. As they are our cultural and historical heritage, these bridges need to be adequately preserved and protected against decay. Some of these bridges require adjustments to meet present-day traffic demands, and some of them have suffered additional damage precisely due to such adjustment activities.

Different types of structural damage may develop during service life of bridges. They are generally due to ageing and material deterioration, increase in traffic load, and external natural factors affecting the bridge structure. In order to accurately assess bridge condition, and to determine an appropriate repair and strengthening method, it is first of all necessary to identify deterioration mechanisms and understand the causes of damage that lead to decay of the structure as a whole or its individual parts. Furthermore, such damage needs to be identified at the existing structure using adequate inspection methods by which structural properties affected by the damage may be established.

\section{Deterioration mechanisms and damage of masonry arch bridges}

As demonstrated by a large number of masonry structures that are still in service after centuries or even millennia of continuous use, no other building material can compete with natural stone in terms of durability [1]. Throughout the history, however, masonry structures with fewer joints have proven to be more resistant because the material in the joints regularly exhibits poorer quality than masonry elements, and so the damage often occurs through failure at the level of joints. The most significant causes of deterioration of masonry structures are:

- salt crystallization which may cause large pressure in the pores of the stone element leading to stone failure, and often creating very weak, almost sandy material,

- dissolution in water which affects some rock types such as carbonate sedimentary rocks, primarily limestone or dolomite, and some sandstone and marble; in this respect it was established that in many urban areas rain exhibits a certain level of acidity that leads to rapid deterioration,

- damage due to action of ice that can occur at low temperatures and exposure to humid environment of stone elements with a higher volume of pores, which can be penetrated by water, and ultimately result in disintegration of such stone elements,

- biological influences such as vegetation roots, ivy branches, birds, and microorganisms, which produce acid and other chemicals that adversely affect carbonate and silicate materials,

- mechanical damage such as weathering of stone-made floors or detachment of structural elements.
The damage to masonry arch bridges is divided into the foundation damage and structural damage, and the latter is further classified into two groups - one is the result of poor structural resistance achieved during construction, and the other is the result of long-term influences over years, which may ultimately reduce resistance of main structural elements [2].

\subsection{Foundation damage}

The main problem with foundation damage is the difficulty to identify such damage. When the river passing under the bridge dries up in summer, it may be easier to detect the condition of bridge foundations. In case of bridges where the water is present throughout the year, the underwater inspection is an appropriate approach. In practice, the first stage is to observe and analyse symptoms that eventually appear on the superstructure as a consequence of rotation or differential movement of foundations. The most common damage to foundations of arch bridges are listed below.

Damage due to element degradation. Most old masonry bridges are built using lime mortar. River water tends to dissolve the lime whose decomposition leads to disintegration of concrete elements made of mortar and lime, usually at the level of masonry bridge foundations. This results in formation of cavities or even in complete disintegration of individual foundation elements. Transport of gravel and sandstone material along alluvial rivers may also lead to erosion of foundation elements, piers or pile caps. Corrosion of steel elements. During the second half of the $19^{\text {th }}$ century and in the first half of the $20^{\text {th }}$ century metallic caissons were often used to construct pile foundations in deep river beds. In other cases, the use was made of sheet piling with metallic elements as a reliable protection against the watercourse. With time, and in presence of moisture, corrosion damage with associated material loss occurred. Material that was initially protected has become vulnerable to erosive action of water and wind. The corrosion resulted in severe damage that affects structural stability and, for that reason, this issue should be taken very seriously.

Damage due to loss of foundation stability can occur as a result of erosion at the bottom of the river bed due to formation of horizontal eddies that develop around these elements. River bed materials are removed by the vertical flow component, i.e. by lifting and pushing forward the existing water.

If any of these occurrences are detected, the maintenance engineer must undertake a detailed visual inspection of the foundation, determine the type and dimensions of the foundations, investigate the soil type, estimate the longitudinal profile and cross section of the river bed, determine the scope of the cleaning activity, and estimate the river flow pattern.

\subsection{Damage due to poor structural capacity}

When considering the issue of damage to masonry arch bridges it is important to know the load causing such damage, 
Table 1. Damage of masonry arch bridges due to poor structural capacity

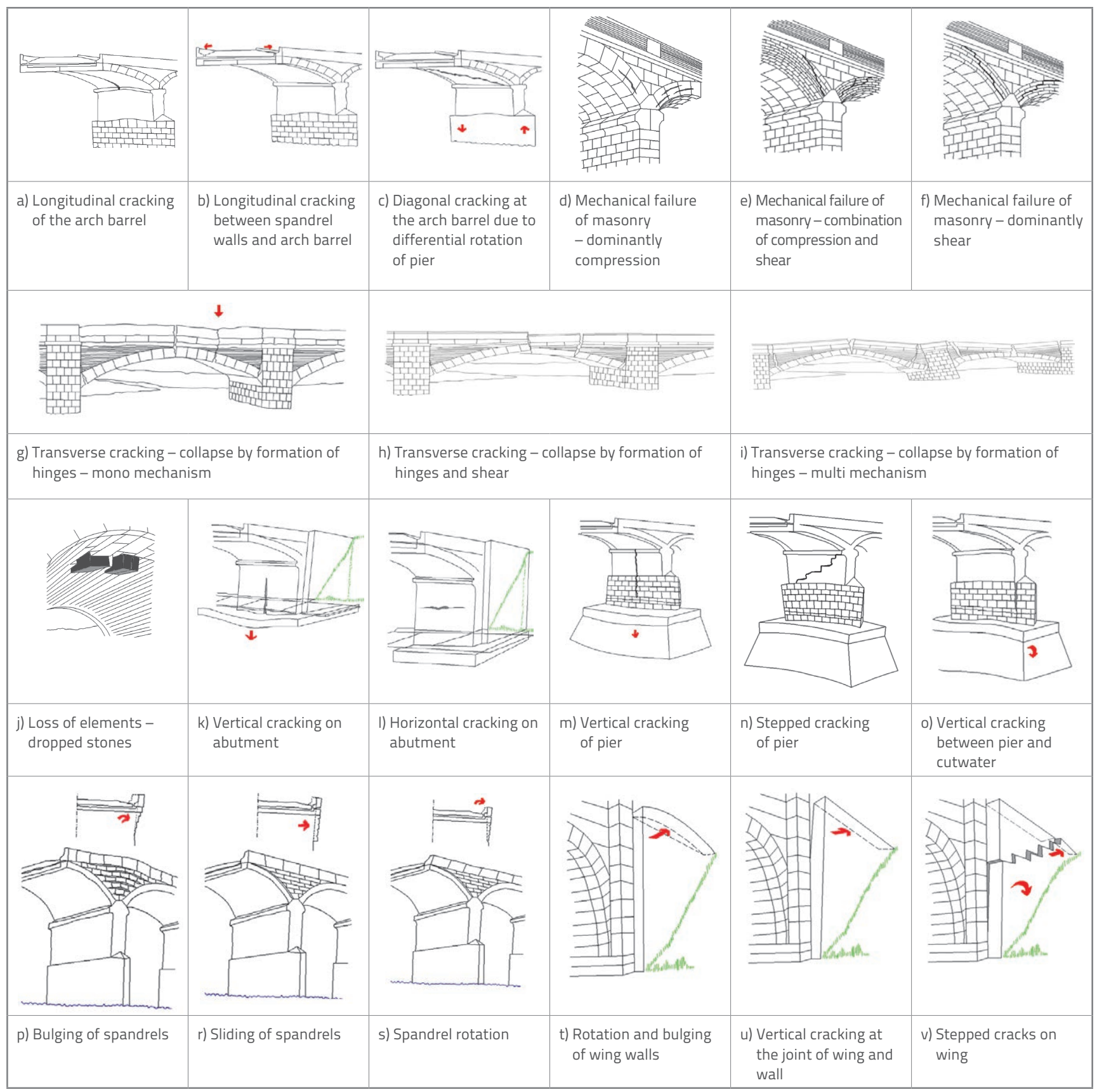

mechanical properties of materials, and general behaviour of the structure. The most common procedure is to classify the damage according to structural element in which it occurs, taking at that into account causes and possible consequences. For example, differential settlement of pier foundations may cause damage to the pier itself but also damage of the barrel, spandrel walls, or drainage system. It can therefore be concluded that the observed barrel damage opens up the possibility of encountering problems in other structural elements as well. The most common damage associated with individual structural elements (arch barrels, piles, abutments, spandrels, spandrel walls, and wing walls)
[2] are listed in Table 1 and are also shortly described below, taking into account the symptom and severity of damage. Longitudinal cracking in the centre of the barrel (a) may occur due to settlement of the centre of pier foundations relative to the edges, or due to transverse bending and axial tension forces present in the arch barrel. This damage may also occur when the position of the track is non-symmetrical with respect to longitudinal axis of the bridge. In brick masonry bridges, where spandrel walls are monolithically connected to the barrel, longitudinal cracks may appear below the inner face of spandrel walls, at the barrel intrados (b). If these cracks exhibit no tendency of further expansion their formation may 
be attributed to different stiffness of spandrel walls (acting as high beams) and the flexible arch barrel, which causes incompatibility of deformations at their connection points. Although these types of damage are not severe, they still need to be checked.

Transverse cracking at the intrados of the arch barrel is the most severe type of damage. These cracks point to the presence of tensile stress which, if neglected, may lead to formation of hinges and to the collapse of the arch. Four hinges should form for collapse to occur under the application of live load (g). The shear mechanism occurs only rarely, and is usually caused by foundation settlement (h). A multi-arch mechanism occurs if seven hinges are formed (i).

Imposed displacements occur due to movement of the abutment and pier footing elements, and result in their undermining. This action is the most important and is responsible for most damage to the masonry arch. The differential settlement of soil below pier and abutment foundations may cause differential displacements between structural elements, which contribute to the development of tensile stresses in the foundations and barrel, causing cracks in masonry bridge elements. Depending on the location and magnitude of foundation displacement and the type of monolithic masonry, the cracking will propagate in either vertical or diagonal direction $(c, k, m, n)$.

Horizontal cracks (I) are common in the centre of abutments of very shallow barrels $f / L<1 / 6$ when the abutments can not withstand horizontal thrust transmitted by arch barrel.

The loss of arch elements may be either due to reduced resistance or reduced durability, or both. If the damage is due to insufficient load carrying capacity, it is usually a symptom of movement of supports at the springing of the arch barrel or, in rare cases, of the loss of axial force in the arch barrel. In addition, such damage may occur due to heavy local impact near the crown of the arch barrel, when the depth of fill over the crown amounts to no more than 0,4 $\mathrm{m}$ (j).

Mechanical failure due to insufficient strength of material in the barrel may occur when the predominant force is compression, and when masonry joints are orthogonal to the thrust line, which will be manifested by cracks that are parallel to the direction of compression (d). The interaction between bending and shear forces, in case of poor material properties, may result in diagonal cracking (e). When the compression force orthogonal to the joint is small, the sliding between the stones or bricks can occur without failure of the material ( $f$ ).

The damage to spandrel walls occurs in form of the bulging of spandrels (p), due to excessive earth pressure from the fill and water retained by the spandrel, and also due to horizontal component of live loads), sliding of spandrels $(r$, when the pressure from the fill, coupled with the horizontal force due to retained water, ballast and external actions, is greater than the stabilising action of the dead load of the spandrel multiplied by the friction coefficient of the joint), and rotation of spandrels (s), when the overturning moment due to the backfill, water, and live loads, is greater than the stabilising moment. These types of damage are typical for bridges with deep but not very wide arch barrels, and with a great depth of fill over the crown.

The damage to wing walls occurs in form of rotation and bulging ( $t$ ) and is due to inefficient drainage of the backfill with obstructed weep-holes, which causes a greater horizontal pressure on the walls. Furthermore, vertical cracking $(u)$ is possible in the joint between the abutment and wing walls due to different movement of wall elements. The abutment is joined to the spandrel and arch barrel, while the wing has a free horizontal movement, particularly at the top. The differential settlement in the wing plane may result in stepped cracking (v). When wing damage is observed, the following measures should be taken: inspection of foundations, identification of possible movements, verification of the type of joint between the abutment and wall, wall backfill check, and actions aimed at improving the drainage system.

\subsection{Damage due to durability problems in the structure}

The durability of masonry arch bridges is affected by climatic actions, deterioration of material properties during service life, and inadequate maintenance.

Climatic actions such are rain, ice, sunlight, and salt carried by the wind, cause damage to the surface of spandrel walls, abutments, joints between masonry elements, etc. The degree and rate of destruction depend on the type of material, quality of joint material, and concentration of adverse effects.

Irregular bridge maintenance contributes to the growth of vegetation and decay of the drainage system, which may result in structural collapse. The growth of vegetation can cause decay of the material in joints, which leads to discontinuity of masonry elements.

Because of clogging of the drainage system, the water accumulates in the backfill, which causes increased pressure on spandrel walls and abutment parts. This pressure may result in greater sliding, bulging and cracking.

\section{Inspection methods}

In order to determine mechanical and physical properties of materials and elements used in masonry arch bridges (such as compressive strength, tensile strength, working diagrams for materials, flexural strength, tensile splitting strength, density, porosity, moisture content, grain structure, and mineralogical composition), samples taken from the bridge must be subjected to destructive testing (permeation, scraping, drilling, cutting, and core extraction). It should be noted that results obtained by most destructive tests provide localised information only, and so they cannot be considered as directly relevant for the entire bridge [3], unless the implemented method has been proven to provide statistically reliable results. 
Slighter penetration into the surface of structural walls is required by minor-destructive testing methods such are boroscopy, flat-jack tests, surface measurements of hardness, pull-out tests, penetration tests, and analysis of cored smalldiameter samples. Minor-destructive testing methods can provide merely the qualitative information on the masonry condition, and should therefore be used for preliminary investigation only.

Non-destructive testing methods such are georadar, infrared thermography, conductivity measurements, and acoustic emission measurements, are more often applied. A more detailed presentation of these methods is given below.

Monitoring systems are occasionally installed on masonry arch bridges in order to follow evolution of damage patterns such as cracks, deformations and moistening. These monitoring methods include hammer tapping, laser profiling, and dynamic and static testing. Monitoring progress of such damage may help us to prevent more serious damage or, in the worst case scenario, the total collapse of the structure. Monitoring may also provide information that can be used to determine root causes of the damage.

\subsection{Suitability of non-destructive testing methods}

While conventional destructive testing methods focus mainly on mechanical characteristics of materials, non-destructive testing methods can provide an overall qualitative review of bridge condition, or some additional information on its internal geometry [4].

Non-destructive testing methods reveal hidden dimensions such are variable barrel thickness, internal ribs and spandrel walls, internal cavities, geometry of piers (solid, in layers, hollow), depth and condition of foundations, and levels of fill. They are applied to examine the type and quality of material (type of stone/brick, mortar, fill material) that may vary in different parts of the overall structure, and to determine damage in form of cracks, cavities, weathering surfaces, ring separations, rinse of fill, infiltration, and waterproofing defects. Furthermore, non-destructive testing methods are used to identify and control prior interventions on the bridge, presence of load, new layers (thickness, quality, separation), injections, and also the equipment such as pipes, and the presence of steel fixtures.

\subsection{Most common test methods}

An overview of most common methods for testing masonry arch bridges, basic concepts, advantages and disadvantages, and suitability of results, is presented in this section $[4,5]$. With georadar testing, electromagnetic impulses are transmitted into the material and recorded by a receiver. Results enable detection of voids, interior geometry, and moisture distribution in both masonry and fill. Advantages and disadvantages of this testing method are:
Table 2. Suitability of some test methods for assessment of geometry, material properties, and defects of masonry arch bridges

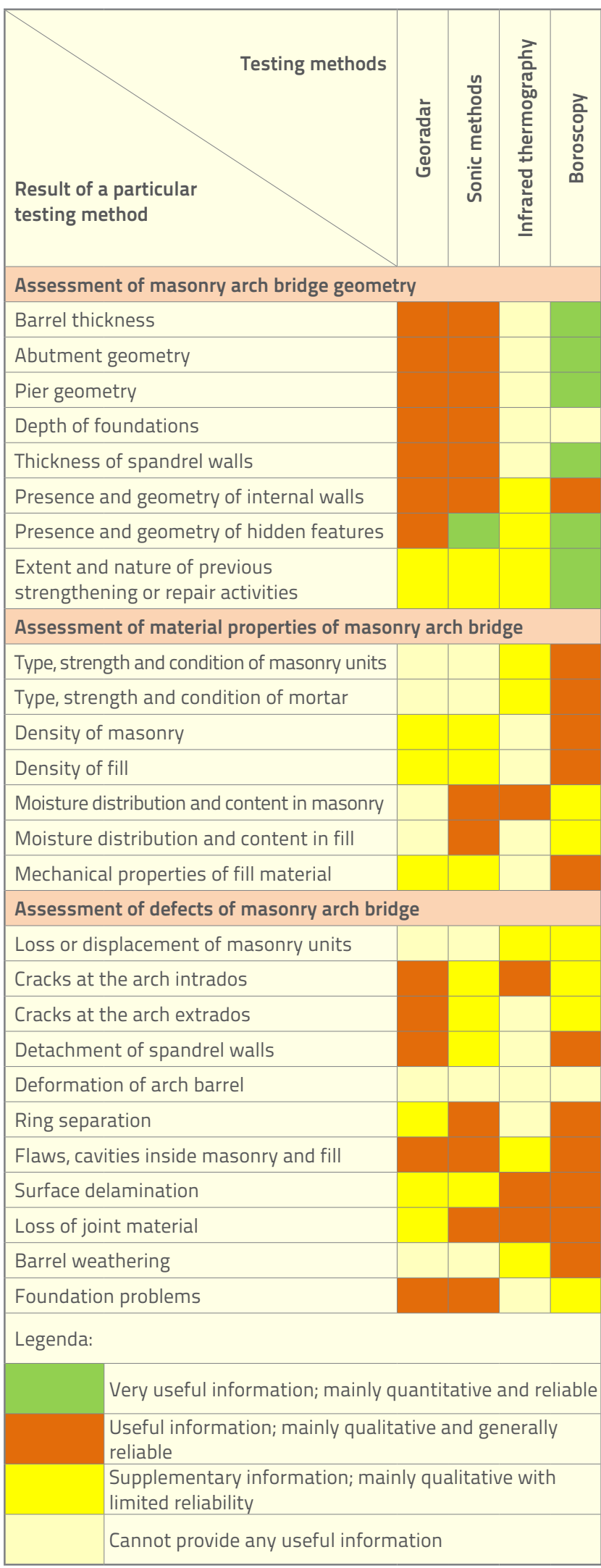


- high penetration depth which provides useful information on internal hidden details about the structure

- an overall qualitative view of the structure

- relatively quick procedure

- specialist required for interpretation

- not applicable in conductive environment.

In case of sonic methods, waves are transmitted through the structure at the velocity that is proportional to the properties of the masonry. Results enable detection of voids, hidden interior geometry, and structural integrity. Advantages and disadvantages of this testing method are:

- high penetration depth which provides useful information on internal hidden details of the structure

- an overall qualitative view of the structure

- time-consuming procedure

- specialist required for calibration and interpretation of results.

The Infrared thermography is a sensing surface radiation using an infrared camera. Results enable survey of cavities and delamination, remote identification of material, detection of wet areas. Advantages and disadvantages of this testing method are:

- an overall qualitative view of the structure

- remote sensing with no direct surface contact

- due to low penetration depth it provides information only within a few centimetres below the surface

- specialist required for interpretation of results

- susceptible to surface conditions.

Boroscopy is a testing with a small camera that is inserted into boreholes drilled into the structure, which allows a detailed analysis along the borehole depth. Results enable visual identification of materials, detection of cavities and defects, and calibration of other tests. Advantages and disadvantages of this testing method are:

- reliable results

- provides only localized information requires drilling of the structure and consequent repair after the testing.

\section{Overview of assessment methods}

Traditional approach to the determination of arch bridge stability dates back to the work of Pippard starting from a two-hinge arch for which the minimum load applied at a fixed position is determined, which causes the arch to turn into a mechanism. This is further extended by Heyman whose theory assumes that the thrust line must become tangential to intrados or extrados in four locations, at which point the structure becomes a mechanism [6]. More recent works [7] are based on the rigid block theory which is considered as the basic model for understanding fundamental behaviour of brick arches. However, this theory uses too many simplifications and assumptions, which frequently leads to large deviations from actual conditions. More realistic solutions require determination of the elastoplastic behaviour of material.

Several methods are nowadays available for assessment of the load-carrying capacity of masonry arch bridges. Conservative methods often underestimate the load carrying capacity which may result in uneconomical or unnecessary mitigation measures being taken to maintain the bridge. [8]. Nevertheless, these methods may provide general information on the bridge load carrying capacity, which gives us a reference point for the next level of assessment.

On the other hand, the use of new sophisticated methods is generally hindered by the difficulty of providing suitable input parameters that need to be collected on the site, which makes the assessment process more demanding, and by inspections and testing of material properties in laboratories, which all prolongs the data processing time. These methods will be used at the highest levels of assessment, as described in references $[4,9]$.

\subsection{Conservative methods of allowable load assessment}

Conservative methods, the results of which are compared to the assessment of the bridge example given in Section 7, are briefly presented in this section. The safe axle load of two side by side wheel loads $W_{A}$ according to the Pippard's elastic method [10]:

$W=\frac{\frac{256 f_{\mathrm{c}} h d}{L}-128 \rho L h\left(\frac{1}{21}+\frac{h+d}{4 a}-\frac{a}{28 d}\right)}{\left(\frac{25}{a}+\frac{42}{d}\right)} ; W_{\mathrm{A}}=2 W$

is based on limiting compressive stress at the crown extrados under the combined dead and live load. The arch is assumed to be parabolic in shape with span/rise ratio $L / a$ of 4 , effective width $b=2 h+30 \mathrm{~cm}$, effective depth $h+15 \mathrm{~cm}$ (the thickness of the fill plus half depth of arch barrel in the crown), compressive stress limit $f_{c}=1400 \mathrm{kN} / \mathrm{m}^{2}$, and the tensile stress limit $f_{t}=700$ $\mathrm{kN} / \mathrm{m}^{2}$. The dispersal of loading in transverse direction with a $45^{\circ}$ load spread angle is assumed with the fill having no structural strength. The density is assumed to be equal to that of the arch ring $\left(\rho=21.44 \mathrm{kN} / \mathrm{m}^{3}\right)$

The Military Engineering Experimental Establishment found that equation (1) given for an idealised arch could be fitted quite well, for given values of allowable and limited stresses, by a nomograph or formula for the provisional axle load (maximum allowable axle load on an axle forming part of a double axled bogie):

$\mathrm{PAL}=740(d+h)^{2} / L^{1,3}$

involving only the arch span $L$ and the total depth $h+d$ at the crown, and this idea was adapted as the MEXE method. In this equation, $d$ is thickness of the arch barrel adjacent to 
the keystone, and $\mathrm{h}$ is the average depth of fill, at the quarter points of the transverse road profile, between the road surface and the arch barrel at the crown, including road surfacing.

This provisional assessment is then modified by factors which allow for the way in which the actual arch differs from the ideal one [11]:

- span/rise factor $F_{s r}$

- profile factor $F_{p}$ which takes into the account the difference between the realistic arch line and a parabolic arch, depending on the arch rise at the quarter points and the rise at the crown,

- material factor $F_{m}$ depending on the material strength of the arch barrel and filling material and its dimensions,
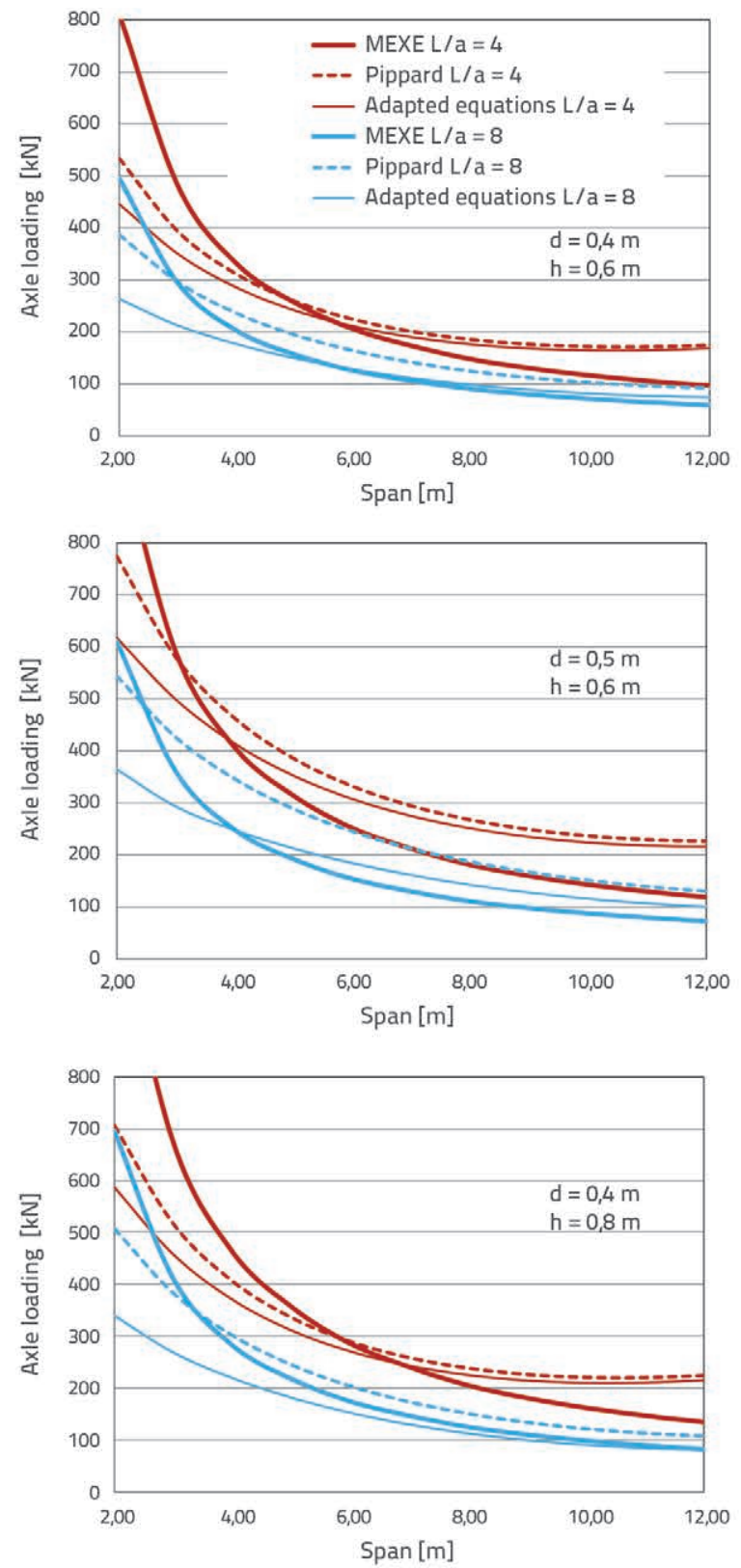

Figure 1. Competence area of each conservative assessment method
- joint factor $F_{j}$ depends on condition of the mortar or some other joint material and takes into account the width of the joints,

- condition factor $F_{C M}$ describes the general arch condition depending on the visual inspection based on an objective assessment of the importance of various cracks and deformations.

In this way the modified axle load, which represents the allowable load (per axle) on the arch from a double-axle bogie configuration with no "lift-off" from any axle (all wheels of the vehicle are assumed to be in full contact with the road surface at all times), is determined:

$\mathrm{MAL}=F_{\mathrm{sr}} \cdot F_{\mathrm{p}} \cdot F_{\mathrm{m}} \cdot F_{\mathrm{j}} \cdot F_{\mathrm{cM}} \cdot \mathrm{PAL}$

Additional axial factors $A_{f}$ are given for converting this result to other axle configurations and for situations where axle 'lift-off' may occur (circumstances when wheels of a multiple axle bogie can partially lose contact with the road surface and transfer some of their load to other axles in the bogie).

New equations for working out the safe axle load of an arch, incorporating axial strain energy effects, are presented In paper [12]. According to these equations, lower carrying capacities have been predicted for relatively small-span bridges:

$W=\frac{\frac{256 f_{\mathrm{C}} h d}{L}-128 \rho L h \frac{1}{1+\lambda}\left\{\left(\frac{1}{21}+\frac{h+d}{4 a}\right)-\frac{a}{28 d}\left[1-7 \lambda-\frac{42(h+d)}{a} \lambda\right]\right\}}{\frac{1}{1+\lambda}\left[\frac{25}{a}+\frac{42}{d}\left(1+\frac{32}{7} \lambda\right)\right]}$

$W_{\mathrm{A}}=2 W ; \lambda=\frac{5}{32}\left(\frac{d}{a}\right)^{2} \int_{0}^{1}(\cos \alpha)^{\frac{4}{3}} d x$

The comparison of results obtained by three methods for determining the axle load for bridge spanning 2 to 12 meters is shown in diagrams given in Figure 1. New equations adapted for smaller spans (thin solid lines), as compared to the original Pippard's equations (dashed lines), produce lower limit values of axle load. The difference is more pronounced with the greater span to rise ratio of the bridge (greater $L / a$ ratio shown in blue lines), and with the greater thickness of the barrel $d$ compared to the depth of the fill above the barrel h. According to additional comparison with the MEXE method (thick solid lines), involving the same material properties, joints and general condition of the bridge, it is evident that new equations for small span bridges are authoritative for the spans of less than $4.0 \mathrm{~m}$ (middle diagram, thin solid lines show the inferior limit axle load compared to the thick lines). As the depth of the fill above the barrel $h$ is larger compared to the thickness of the barrel $d$ (middle diagram $h / d=1,2$, upper diagram $h / d=1,5$, bottom diagram $h / d=2,0$ ), these new formulas will become authoritative even for larger spans. With higher span to rise ratio $L / a$, new formulas may be 
authoritative even for larger spans (up to 12 meters, as shown in the bottom diagram).

The analyses conducted in this study show that the assessment based on both methods (new equations adapted for smaller spans and MEXE method) needs to be conducted to obtain results for an individual bridge, and thus the authoritative value of the limit axle load will be established.

\subsection{Sophisticated methods}

The use of sophisticated computerised techniques for the assessment of the load carrying capacity and stability of masonry arch bridges has increased in recent times. These techniques are characterised by high level of accuracy, but only if numerous and detailed input data are provided. They are based on finite element methods, discrete element methods, and their combination $[3,4,13]$.

The RING software $[6,7,14,15]$ rwas developed in association with the International Union of Railways (UIC) and it has been extensively validated against laboratory test data on ultimate load, as accumulated over the past few decades. This software idealizes a bridge as a series of blocks separated by contacts where sliding, crushing or hinging can occur. Fill material above the arch barrel is modelled to give passive restraint (restraint from backfill elements) and to allow for dispersal of live load. RING uses mathematical optimization to directly identify the state of collapse, computing the load factor which, when applied to the specified live load, will lead to collapse. This includes the thrust zone at collapse which gives a visual indication of both the position of the line of compressive force, and the minimum amount of material needed to resist it. In the Archie-M $[6,16]$, the traditional thrust line analysis is used in combination with a zone of thrust to model the finite crushing strength. The thrust line is found with a three hinge system. Hinge positions are found by assuming that there must be a minimum total energy in the system. The main purpose of this software is to show that a required load can be supported, and that the collapse load can be estimated by varying the load factor until the thrust line touches an extra border of the arch making a fourth hinge. The lateral earth pressure of the fill is always at rest pressure, and the live load lateral earth pressure can be set to the active or at-rest pressure. A proportion of passive restraint pressure can be added to ensure that the thrust remains in the arch. The live load distribution is also taken into account.

\section{Additional considerations}

Existing masonry arch bridges have been in use for many years during which many of them have been repaired and adjusted to meet present day traffic load and traffic width requirements, usually by adding new concrete deck, pavement layers, and new equipment.

Despite the fact that the total new additional dead load and required traffic load, and the spreading of such load through all layers, needs to be considered in the load carrying capacity of the barrel, additional effects of these changes should also be taken into account. Namely, the present-day weight and speed of vehicles may often cause serious damage to bridge structure due to vehicle impact against the safety barrier.

As described in more detail in paper [17], the level of deformation, i.e. displacement of the restraint system, has a great influence on the impact force value, which is associated with the stiffness of the barrier fixing in the superstructure and, consequently, with effects on the bridge structure. If the maintenance of the existing bridge includes installation of the new safety barrier for which the bridge structure may not be able to handle the impact of a real vehicle, then the upgrading design needs to be developed.

An average force of a real vehicle impact acting perpendicular to the barrier may be determined based on the vehicle mass $m$, dimensions ( $c$ may be taken as a half of the vehicle length, $b$ as a half of a vehicle width), velocity $v$, and the angle of impact $\alpha$ :

$$
\overline{\mathrm{F}}=\mathrm{m} \cdot \overline{\mathrm{a}}_{\mathrm{n}}=\frac{\mathrm{m} \cdot \mathrm{v} \cdot \sin \alpha)^{2}}{2 \cdot\left[\mathrm{c} \cdot \sin \alpha+\mathrm{b}(\cos \alpha-1)+\mathrm{s}_{\mathrm{b}}\right]}
$$

Additionally $s_{b}$ is the maximum dynamic deflection of traffic face of the barrier (more precisely the sum of the barrier deflection plus part of vehicle crumpling), and may be replaced with the working width of the restraint system $W_{N}[17,18]$. Simultaneously with horizontal force of the impact, the vertical force of vehicle weight should be considered, together with their proper distribution widths.

With the inversed procedure, for the required containment level and working width level of the barrier, the limit velocity of the real vehicle (at least equal to the common average speed of the vehicle considered) may be established. If the resulting limit velocity is less than the average velocity of the real vehicle, the speed limit at the bridge should be reduced, or the load capacity of the critical element needs to be assessed and optionally upgraded.

\section{Original preliminary assessment procedure}

The original procedure of preliminary assessment has been developed on the basis of the state-of-the-art information on the assessment of small-span masonry arch bridges, and according to an additional analysis of the strengthening and adjustment of these bridges to modern traffic demands during their lifetime. The procedure can be used to determine the need for strengthening the barrel itself and/or for subsequent strengthening of the deck slab. First of all, it is necessary to collect appropriate data about the bridge, which implies surveying that will provide basic geometrical data, then testing material in the barrel and fill, deck slab concrete testing, and the unavoidable visual inspection to determine general condition of the bridge. This is followed by barrel 


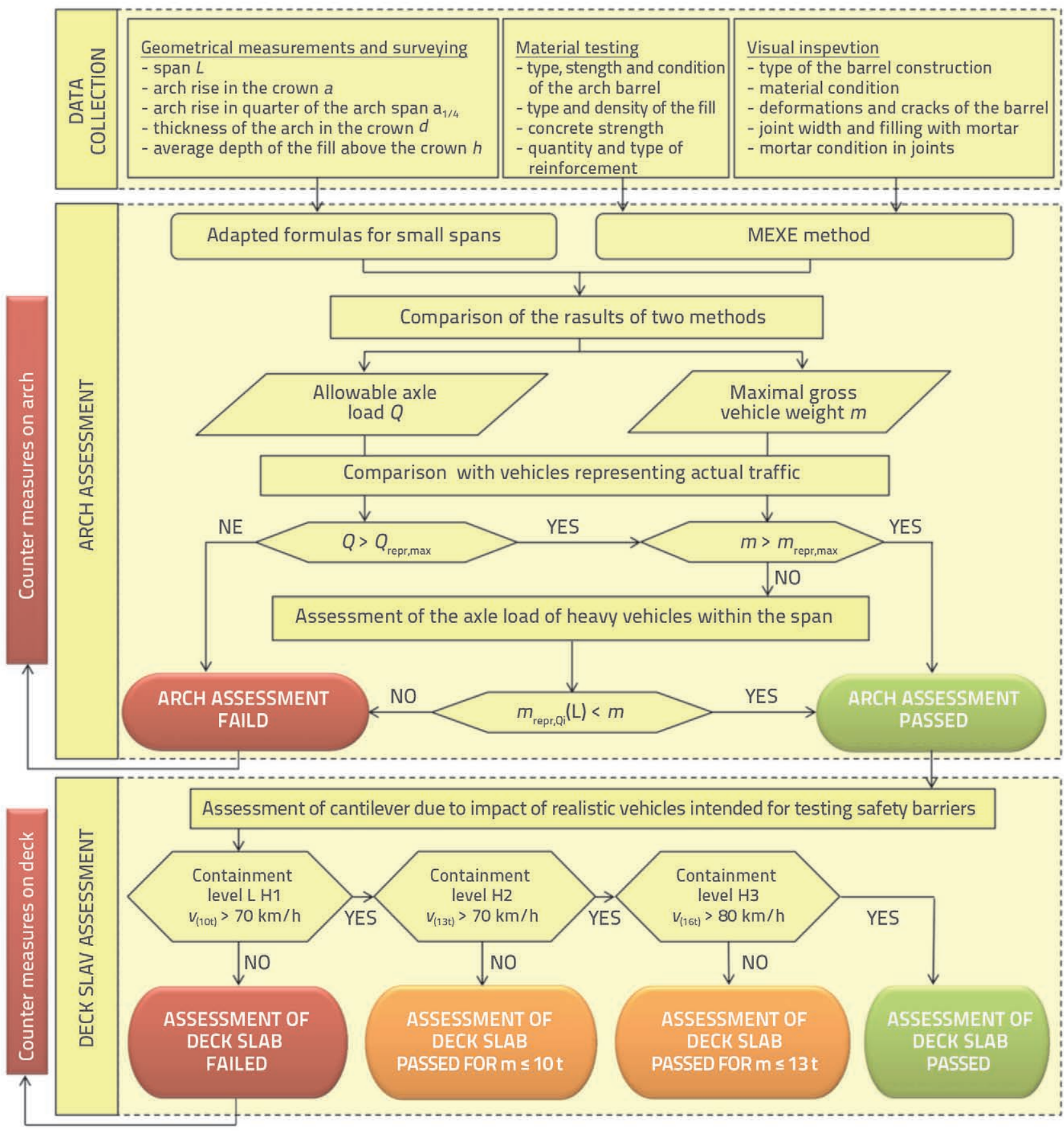

Figure 2. Flow chart for preliminary assessment of small-span masonry arch bridges with concrete deck slab

assessment using two conservative methods, MEXE method and Pippard's method adjusted to small-span bridges. One of these methods, depending on relations between geometrical parameters of the bridge, will be competent, and the result will be expressed as the allowable axle load and the maximum allowed gross vehicle weight.

In order to determine whether the barrel meets traffic demands, these results are compared with axle loads and total weight of heavy vehicles that represent the actual traffic at a given location of the bridge $[19,20]$.
If the allowable axle load obtained is lower than the axle load of a vehicle representing actual traffic, then the barrel assessment failed and counter measures are necessary. The barrel needs to be strengthened or traffic restrictions should be imposed. If additional inspections of the arch bridge are financially feasible, it is recommended to further assess the bridge using more sophisticated methods that may reveal bridge redundancy.

If the allowable axle load obtained is greater than the axle load of any vehicle representing actual traffic, it can still 
happen that the total allowable weight does not satisfy the assessment. Therefore, further analysis of the axle spacing of the heaviest axle loads compared to the bridge span is necessary, in order to determine whether the weight of the vehicle directly in the span is lower than the allowable one.

If the allowable axle load and gross vehicle weight meet actual traffic demands, the ultimate limit state of the arch will be assessed as satisfactory.

Even when the barrel is assessed as satisfactory, further assessment of the deck slab, taking into account the real vehicle impact against safety barrier, will be needed. As shown in Figure 2, possible results are: the slab deck does not meet even the lowest required containment level of the safety barrier type $\mathrm{H} 1$; the slab deck meets the required limited containment level, and the access of the vehicles with the weight greater than the limited one for a given containment level at the bridge is restricted; the slab deck assessment is completely satisfactory and no counter measures are necessary.

The application of this method is presented on a real bridge in the next section of this paper.

\section{Example of assessment with comments}

A masonry arch bridge comprising three stone segmental arches was built more than 110 years ago $[9,21]$. The original bridge was $5.85 \mathrm{~m}$ in width. In the 1950s, the bridge was widened to $7.0 \mathrm{~m}$ and an additional $15 \mathrm{~cm}$ thick concrete deck was added. Ten years later, the bridge was widened to the total of 9.0, $\mathrm{m}$ with an additional $16 \mathrm{~cm}$ thick concrete deck and with the cantilever $107.5 \mathrm{~cm}$ in length. Spans of parabolic arches are $8.65 \mathrm{~m}$, with the rise of $1.97 \mathrm{~m}$. The spans are supported with pier-walls of variable thicknesses, and with abutments featuring vertical front walls and parallel wing walls.

\subsection{Bridge condition based on visual inspection}

Bridge foundations are on sound solid rock and no scour or settlement is visible. The abutment, pier-walls, and arch, show no signs of insufficient capacity for the loads and traffic for which the bridge is in service today. There are no signs of an insufficient arch thickness or an insufficient material strength as shown in Figures d), e) i f) in Table 1, and no signs of distortion or ring separation from the rest of the structure, as shown in Figure b) in Table 1. In addition, there are no signs of arch stone erosion or movement, as shown in Figure j). Black marks on the surface of arch barrels point to the moisture problem and to abundant water seepage through the structure. However, despite its presence, it seems that water did not cause any major structural damage.

The inspection of arch barrels leads to the conclusion that some kind of repointing works and small reparations were conducted, probably simultaneously with the last bridge widening works. It is estimated that some loose or friable mortar was removed and filled with new material. Small cracks are present on some old mortar joints, but also on new joints, which is however not a serious problem. All cracks spread in longitudinal direction, but not even close to the ones shown in Figure a) in Table 1. On the other hand, cracks in transverse direction, which may have caused cause the condition presented on Figure c), are almost not present at all.

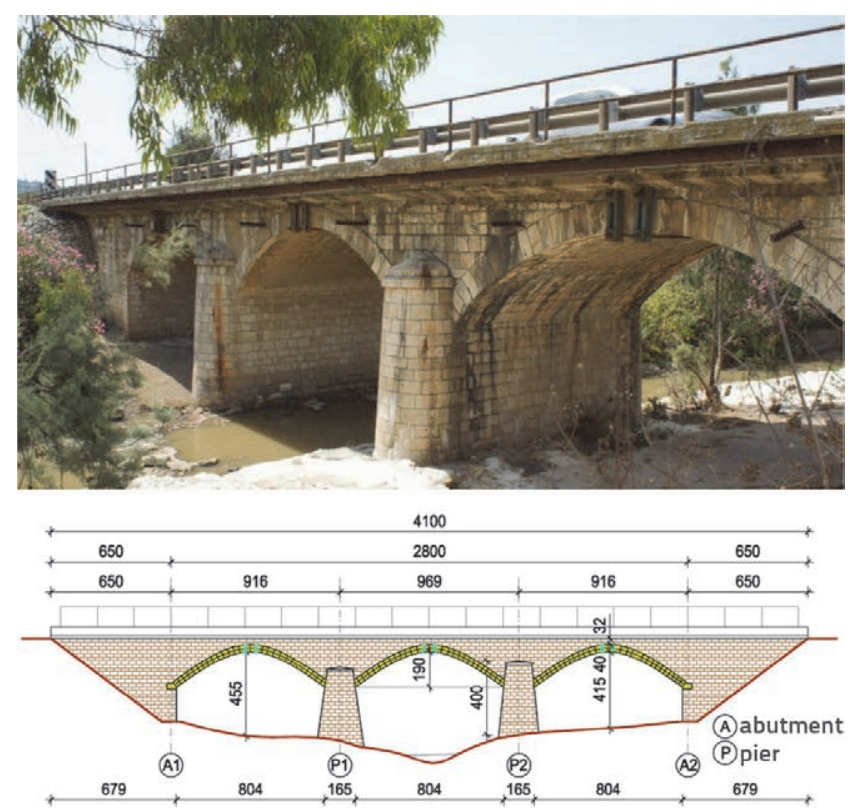

Figure 3. Example of a masonry bridge

The inspection of spandrel walls shows that they are in good condition, with one local exception on the upstream side near abutment where local signs of spandrel wall bulging were registered. This bulging also changed the colour compared to the rest of the stones. Such damage is comparable to the one shown in Figure p), Table 1. It is possible that this bulging occurred during one of the road widening operations, as an adjustment of the structure to new additional load. The other possibility is retention of water in fill material. There are no signs that this movement occurred recently or that it is currently in progress.

Other types of damage shown in Table 1 have not been observed. Based on visual inspection, it may be stated that all masonry parts of a bridge are in a good condition, and that there are no signs that would point to a possible serious deterioration in the near future.

The type of the bridge masonry is a regularly laid natural stone. Pier-walls are either completely made of natural stone or just the outside is built of natural stone while the interior is filled with a lower grade material. Unlike the piers, it may be concluded with a great certainty that abutments are hollow and filled with a lower grade material. At the downstream side of the bridge, in the spandrel wall near abutment, there is a circular opening through which the interior of the bridge can be observed. As the 
infill made of loose stone material can clearly be seen through this opening, it may reasonably be expected that the entire bridge fill is made of this kind of loose stone material.

Lower cantilever deck is in a relatively good condition that corresponds to the normal life span of 60 years. A slight deck damage may locally be observed. The change of colour due to long-term weather exposure can also be observed at some points. The damage is minimal and does not pose a serious problem for the safety of the structure.

Unlike the lower deck, the upper cantilever deck is in a very poor condition. Along the entire length of the bridge, the areas with separation of the protective concrete layer may be seen, which has resulted in visible corrosion of reinforcement along the entire cantilever part of the upper deck. This is probably due to an insufficient concrete cover defined in the design, and to an inadequate realization of works. Also, numerous cracks have been observed in the transverse direction of the deck. The poor condition of the cantilever part of the upper deck is a threat to the security and stability of safety barriers and pedestrian footway at the bridge, and further accelerated deterioration of the deck is to be expected.

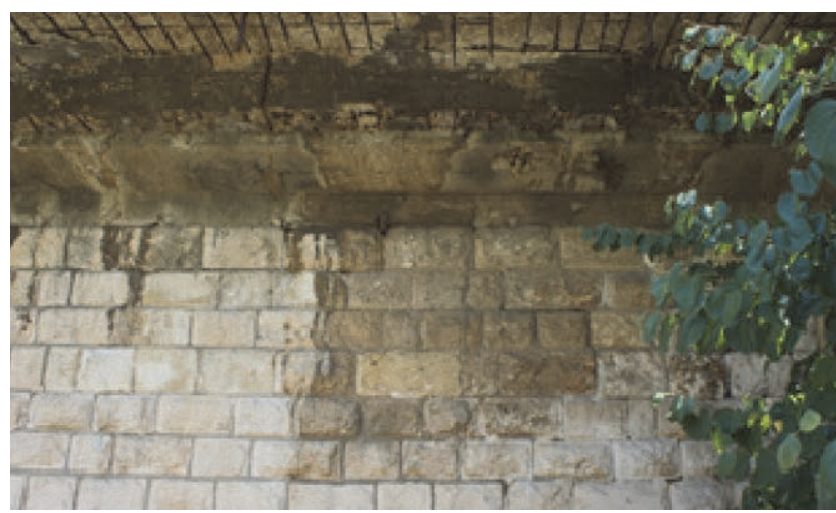

Figure 4. Bulging and colour change at the spandrel wall

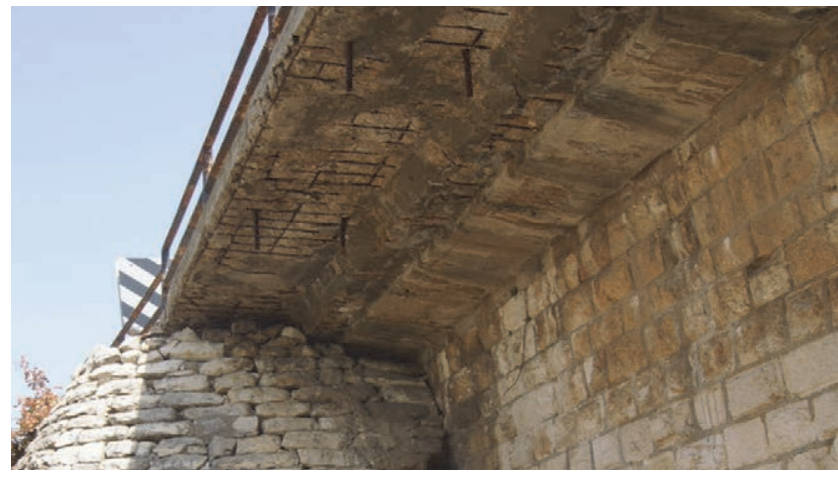

Figure 5. Poor condition of bridge cantilevers

\subsection{Arch assessment}

Assessment of the bridge arch was performed using three methods described in Section 4.1. Input data were defined based on available documentation of the bridge, surveying and geometric measurements, and evaluation of bridge condition based on visual inspection.

According to the Pippard's method, the maximum allowable axle load is 18.7 tonnes. Based on the modified MEXE method, the maximum allowable axle load is 31.2 tonnes for one-axle, $15.6 \times 2=31.2$ tonnes for two-axle, and $18.7 \times 3=56.1$ tonnes for the three-axle bogie. According to new formulas developed for short span bridges, maximum allowable axle load is $\mathbf{1 7 . 7}$ tonnes. The gross vehicle weight and the maximum axle load are rounded off to 31 tonnes and 15 tonnes, respectively [22].
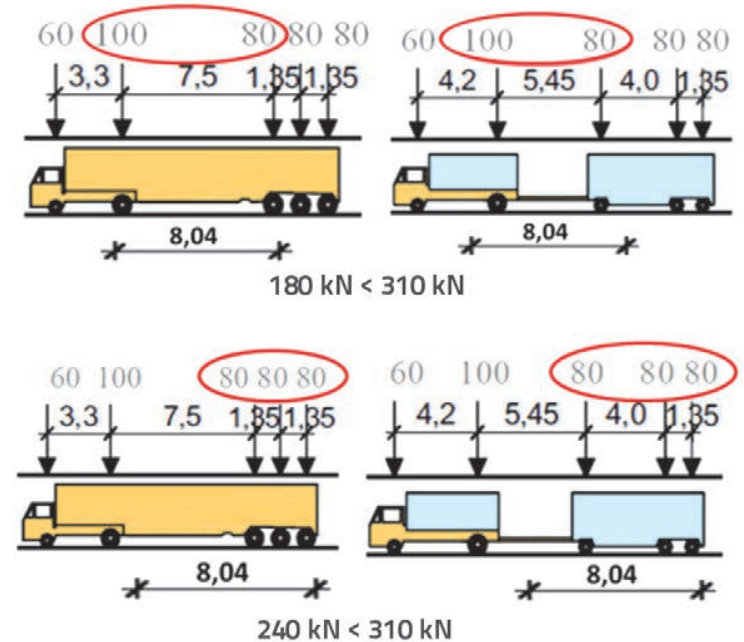

Figure 6. Influence of axle distances of the heaviest axle loads of the representative vehicles type 5 (tug trucks) and 6 (tracks with trailers) acting on the bridge with the span smaller than the total vehicle length

If these results are compared with representative vehicle models $[19,20]$ on Croatian roads, it can be established that all vehicles satisfy the maximum allowable axle load requirement, but tug trucks (as vehicles models 5) and trucks with trailers (as vehicles models 6) do not satisfy the gross vehicle weight limit. However, taking into account the axle distance and the bridge span of $8.04 \mathrm{~m}$ these vehicles satisfy the total vehicle weight requirement, which can be a direct span load as well.

\subsection{Cantilever assessment}

Due to poor condition of the second widening of the deck, the assessment of the deck cantilever was performed. The impact of a real 10-tonne vehicle on the guardrail type $\mathrm{H} 1$, and of a 13-tonne vehicle on the guardrail type $\mathrm{H} 2$, was investigated for an accidental load situation.

Maximum vehicle limiting speeds [22] were established based on the inversed procedure [17] for definition of an average vehicle impact force for the required containment level testing and guardrail deformation level. For a 10-tonne vehicle, the maximum limiting speed is $80 \mathrm{~km} / \mathrm{h}$, while for a 13-tonne vehicle the maximum limiting speed is just $20 \mathrm{~km} / \mathrm{h}$. The use of vehicles characterized by higher mass would jeopardize safety of the bridge cantilever, and of the entire bridge. Namely, 
heavier vehicles would induce design bending moment $M_{S d}$ in excess of the resistance bending $M_{R d}$ calculated on the basis of the as-built cantilever reinforcement.

\subsection{Results overview and proposal of remedial measures}

According to conservative arch assessment methods, the gross vehicle weight limit would amount to 31 tonnes. However, due to poor condition of concrete and an inadequate as-built reinforcement, the deck cantilever would not be able to resist the vehicle impact on the guardrail.

Based on these assessment results, an appropriate repair of concrete deck is proposed. In addition, the existing deck cantilever was analysed for the persistent load situation with the new European traffic load model (one wheel load of $120 \mathrm{kN}$ and a uniformly distributed pedestrian load of $5 \mathrm{kN} /$ $\mathrm{m}^{2}$ ). It was concluded that the as-built reinforcement is not sufficient according to contemporary reliability demands. Cantilever replacement with an adequate new reinforcement is proposed (Figure 7) based on the analyses according to normative Eurocode traffic load models and realistic vehicle impacts on guardrails type $\mathrm{H} 1$ and $\mathrm{H} 3$.
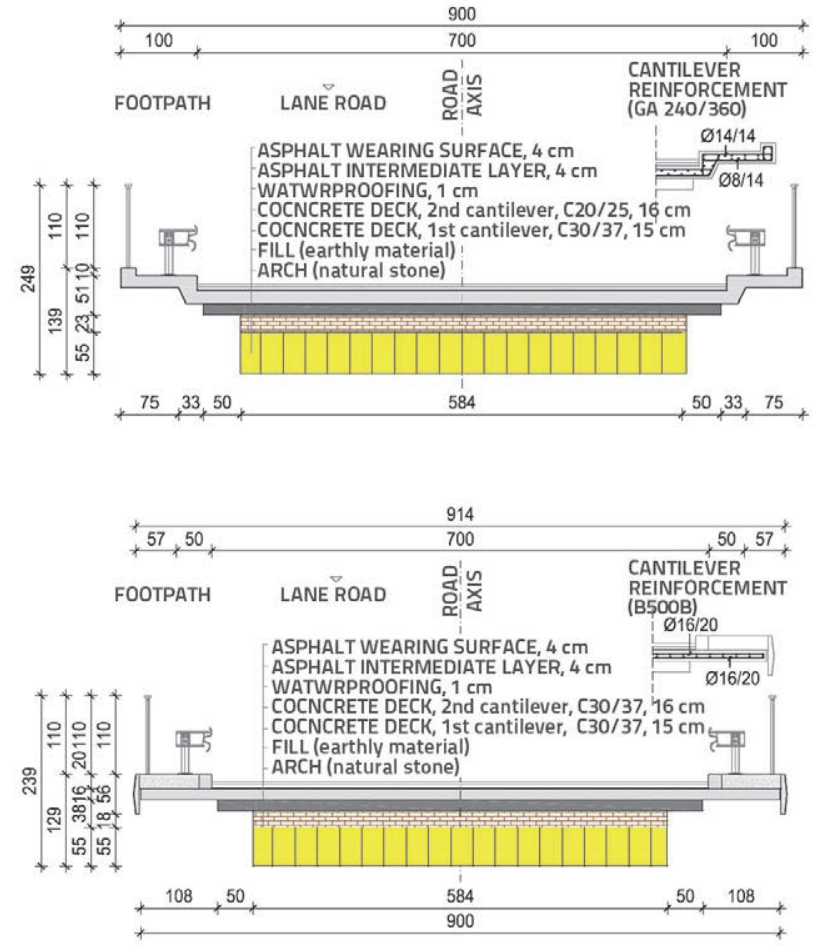

Figure 7. Cross-section of the existing bridge deck (top figure) and a new bridge deck proposal (bottom figure)

\section{Conclusion}

Adequate assessment of the load-carrying capacity of masonry arch bridges is a key to their continued service, and is aimed at ensuring that strengthening is used where and when needed only. Several assessment methods are currently available, and all are based on sophisticated computer programmes for assessing stability and ultimate state of arches. They are characterised by high accuracy but only if numerous and detailed input data are provided.

In practice, structures often have to be assessed on the basis of very limited data, which results in rather subjective estimations. Therefore, conservative methods will often be of great importance, particularly in the scope of preliminary assessment. Although they often underestimate the load carrying capacity of an arch, they may provide general information on the bridge, which gives us a reference point for the next level of assessment. First of all, it is necessary to know deterioration mechanisms and understand causes of damage that bring about a premature decay of the structure. Furthermore, such damage needs to be identified at the existing structure, using adequate inspection methods, so that structural properties affected by such damage may be established. Therefore, this paper gives an overview of most common types of damage, and methods that are most commonly used for inspection of masonry structures.

Based on the presented example of a bridge built more than 100 years ago, we may notice that changes made to the masonry arch bridge due to present-day traffic demands (double strengthening with concrete deck slabs) may further limit its capacity. Additional criteria such as durability of safety barriers may be crucial in restricting bridge traffic, or in the decisionmaking process aimed at defining strengthening requirements for this bridge.

An original procedure for preliminary assessment of small-span masonry arch bridges adjusted to present-day traffic demand during their lifetime, is proposed in this paper, and implemented in the assessment of an actual bridge. First of all, it is necessary to collect bridge data using visual inspection, geometrical measurements, surveying, and material testing. This is followed by barrel assessment using two conservative methods that are relevant for small spans, and for comparison of the allowable axle load and maximum gross vehicle weight with the presentday traffic demands. Regardless of barrel assessment results, the next step is to assess the deck slab with regard to the impact of actual vehicles against safety barriers so as to determine the containment level.

The arch is assessed using the modified MEXE method for the one-axle, two-axle, and three-axle bogie, and according to new formulas developed for short span bridges, which resulted in the maximum gross vehicle weight of 31 tonnes, and the maximum axle load of 15 tonnes.

Additionally, the bridge cantilever is assessed for the possibility of vehicle impact against the safety barrier. Due to poor condition of the second deck widening, the maximum limiting speed of only $20 \mathrm{~km} / \mathrm{h}$ was established for the 13-tonne vehicle, which clearly shows that the effect of a greater-mass vehicle would jeopardize safety of the bridge deck cantilever. Therefore, cantilever replacement is proposed as a repair measure. The new solution was verified using analyses according to normative Eurocode traffic load models, and through realistic vehicle impacts against guardrail types $\mathrm{H} 1$ and $\mathrm{H} 3$. 


\section{REFERENCES}

[1] Radić, J.: Trajnost konstrukcija 1, Hrvatska sveučilišna naklada, Jadring, Sveučilište u Zagrebu - Građevinski fakultet, Zagreb, 2010.

[2] Ozaeta García-Catalán, R., Martín-Caro lamo, J.A.: Catalogue of Damages for Masonry Arch Bridges - Final draft, Improving Assessment, Optimization of Maintenance and Development of Database for Masonry Arch Bridges (UIC project I/03/U/285), Paris, June 2006.

[3] Orbán, Z.: UIC Project on assessment, inspection and maintenance of masonry arch railway bridges, $\mathrm{ARCH}^{\prime} 07$ : $5^{\text {th }}$ International Conference on Arch Bridges, pp. 3-12, 2007.

[4] Orbán, Z., Gutermann, M.: Assessment of masonry arch railway bridges using non-destructive in-situ testing methods, Engineering Structures 31, pp. 2287-2298, 2009.

[5] Guidelines on non-destructive testing of bridges, BS-103, Government of India, Ministry of railways, August, 2009.

[6] Audeneart, A., Beke, J.: Applicability analysis of 2D-models for masonry arch bridge assessment: Ring, Archie-M and the elasto-plastic model, Wseas transactions on applied and theoretical mechanics, Issue 4, Volume 5, pp. 221-230, 2010.

[7] Gilbert, M., Melbourne, C.: Rigid-block analysis to masonry arches, Structural Engineering 72, pp. 356-361, 1994.

[8] Orbán, Z.: Improving Assessment, Optimisation of Maintenance and Development of Database for Masonry Arch Bridges, overview of the Research Project for International Union of Railways (UIC), 2007.

[9] Kindij, A., Radić, J., Mandić, A.: Masonry arch bridge evaluation, 3rd Chinese-Croatian Joint Colloquium: Sustainable arch bridges, Zagreb, Croatia, pp. 325 - 334, 2011.

[10] Wang, J., Melbourne, C., Tomor, A.: MEXE method for masonry arch bridge assessment, presentation for the Masonry Arch Bridges Masterclass, University of the West of England, 2010.

[11] Design manual for roads and bridges. 2001. Volume 3: Highway structures - inspection and maintenance, Section 4: Assessment, BA16/97
[12] Wang, J., Melbourne, C., Tomor, A.: Development of Pipard's elastic method for the assessment of short span masonry arch bridges, ARCH'10: $6^{\text {th }}$ International Conference on Arch Bridges, pp. 490-497, 2010.

[13] Brencich, A, Gambarotta, L.: Guide to the high level Assessment of Masonry Bridges, prezentacija za UIC Workshop on Masonry Arch Bridges, $9^{\text {th }}$ May 2007, Paris, France

[14] Gilbert, M.: Limit analysis applied to masonry arch bridges: stateof-the-art and recent developments, $\mathrm{ARCH} 07: 5^{\text {th }}$ International Conference on Arch Bridges, pp. 13-28, 2007.

[15] Limit state: RING Manual, Version 3.0, LimitState Ltd, November 2011.

[16] Archie-M: Masonry Arch Bridge and Viaduct Assessment Software, Version 2.3.1, User Guide, OBVIS Ltd, United Kingdom 2008.

[17] Mandić, A., Šavor, Z., Grgić, V.: Zaštitne ograde na mostovima, Gradevinar 63 (2011) 12, pp. 1053 - 1160.

[18] EN 1317-1: Road restraint systems - Part 1: Terminology and general criteria for test methods, European Committee for Standardization, Bruxelles, August 2010.

[19] Mandić, A., Radić. J., Šavor, Z.: Limit States of Existing Bridges, Proceedings of the Joint IABSE-fib Conference Dubrovnik 2010: Codes in Structural Engineering - Developments and Needs for International Practice, Cavtat, Croatia May 3-5, SECON-CSSE, pp. 1169-1176, 2010.

[20] Mandić, A., Radić. J., Šavor, Z.: Ocjenjivanje graničnih stanja postojećih mostova, Građevinar 61 (2009) 6, pp. 533 - 545., (in Croatian).

[21] Kindij, A., Radić, J., Mandić, A.: Expert Opinion on Masonry Arch Bridge, 2010.

[22] Vasilj, M.: Ocjenjivanje zidanih svodenih mostova, diplomski rad. 2011., (in Croatian). 